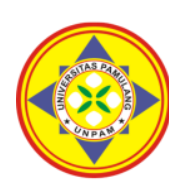

\title{
PENGARUH DISIPLIN KERJA TERHADAP KINERJA KARYAWAN PT TRANS RETAIL INDONESIA
}

\author{
${ }^{1 *}$ Hendri Prasetyo, ${ }^{2}$ Lia Vidiawati \\ Universitas Pamulang, Tangerang Selatan, Banten, Indonesia \\ *dosen00806@unpam.ac.id
}

\begin{abstract}
Abstrak
Penelitian ini bertujuan untuk mengetahui pengaruh disiplin kerja karyawan pada PT Trans Retail Indonesia dan kinerja karyawan di PT Trans Retail Indonesia. Metode penelitian ini dilakukan dengan menggunakan metode kuantitatif. Sampel yang digunakan adalah karyawan PT Trans Retail Indonesia divisi Operation Local Buyer, dimana jumlah sampel yang ditetapkan pada penelitian ini sebanyak 75 responden dengan menggunakan metode sampel jenuh. Teknik analisis menggunakan analisis statistik dengan pengujian regresi, korelasi, determinasi dan uji hipotesis. Hasil penelitian ini pelatihan dan kompensasi secara simultan berpengaruh signifikan terhadap prestasi kerja sebesar $52,4 \%$, uji hipotesis diperoleh signifikansi 0,000 < 0,05.Prestasi kerja berpengaruh signifikan terhadap kinerja karyawan sebesar 40,0\%, uji hipotesis diperoleh signifikansi 0,000<0,05.
\end{abstract}

Kata Kunci: Disiplin Kerja, Kinerja Karyawan

\section{Abstract}

This study aims to determine the effect of employee discipline at PT Trans Retail Indonesia and employee performance at PT Trans Retail Indonesia. This research method is carried out using quantitative methods. The sample used was employees of PT Trans Retail Indonesia Operation Local Buyer division, where the number of samples set in this study were 75 respondents using the saturated sample method. The analysis technique uses statistical analysis with regression, correlation, determination and hypothesis testing. The results of this study that training and compensation simultaneously have a significant effect on work performance by 52.4\%, hypothesis testing is obtained a significance of $0.000<0.05$. Work achievement has a significant effect on employee performance by $40.0 \%$, hypothesis testing obtained a significance of $0.000<0,05$.

Keywords: Work Discipline, Employee Performance

\section{PENDAHULUAN}

Organisasi merupakan sarana atau alat untuk mencapai tujuan. Oleh karena itu organisasi merupakan suatu wadah yang didalamnya terdapat aktivitas orang-orang dalam bekerjasama untuk mencapai suatu tujuan tertentu yang telah di tentukan bersama. Setiap organisasi pastilah memiliki tujuan yang berbeda-beda.

Dalam organisasi ada yang memiliki tujuan pemerintah dan ada juga yang non pemerintah. Tujuan pemerintah apabila organisasi itu berada di wilayah pemerintahan dengan tujuan pencapaian tujuan negara misalkan untuk mewujudkan kesejahteraan sosial bagi seluruh rakyat Indonesia, sedangkan tujuan non pemerintahan bukan menjadi bagian dari pemerintah, birokrasi ataupun negara, sebagian besar hanya untuk mencari keuntungan.

Dalam usaha pencapaian tujuan sangat tergantung pada faktor manusia, karena faktor manusialah yang menentukan keberhasilan suatu organisasi, dan manusialah yang menjalankan kegiatan untuk pencapaian tujuan. Setiap orang yang ada dalam sebuah organisasi pasti memiliki tujuan, dan tujuan yang hendak dicapai haruslah sama serta selaras, agar tidak ada perselisihan antara anggota.

Dalam setiap organisasi disiplin merupakan suatu kesadaran akan hak dan kewajiban pegawai untuk menjalankan tugas sesuai dengan tugas pokok dan fungsinya. Disiplin merupakan suatu keadaan dimana orang-orang yang tergabung dalam organisasi tunduk pada peraturan yang ada 
dengan rasa senang hati, sedangkan kerja adalah segala aktivitas manusia yang dilakukan untuk mencapai tujuan yang telah ditetapkan.

Disiplin kerja karyawan sangat berpengaruh terhadap kinerja, terutama dalam hal perilaku, kemampuan, pelaksanaan serta tanggung jawab dalam setiap pelaksanaan pekerjaan. Setiap organisasi publik membutuhkan sumber daya manusia yang bekerja secara efektif dan efisien untuk pencapaian tujuan organisasi. Setiap pegawai dapat melaksanakan tugasnya dengan hasil optimal apabila mereka mempunyai disiplin kerja yang tinggi. Ciri utama dari disiplin kerja adalah adanya keteraturan dan ketertiban akan pelaksanaan tugasnya.

PT Trans Retail Indonesia adalah perusahaan yang bergerak dibidang retail diindonesia, yang sudah banyak memiliki investor. Agar seluruh kegiatan tercapai sesuai dengan harapan, namun yang terjadi manajemen pencapaian kinerja yang diharapkan belum maksimal mengingat kurangnya disiplin kerja yang dimiliki oleh karyawan dan berdasarkan hasil penelitian dikantor PT Trans Retail Indonesia masih melihatkan kinerja karyawan yang rendah.

Dari latar belakang tersebut diatas, maka peneliti menilai perlu adanya studi untuk menganalisa pengaruh kedisiplinan karyawan dengan berjudul:"Pengaruh Disiplin Kerja Terhadap Kinerja Karyawan PT. Trans Retail Indonesia".

\section{TINJAUAN PUSTAKA}

\section{Disiplin kerja}

Menurut Hasibuan (2013:193) berpendapat bahwa kedisiplinan adalah kesadaran dan kesediaan seseorang menaati semua peraturan perusahaan dan norma-norma sosial yang berlaku. Berdasarkan pengertian diatas disimpulkan bahwa disiplin kerja merupakan suatu sikap, tingkah laku, dan perbuatan yang sesuai dengan peraturan baik tertulis maupun tidak tertulis, dan bila melanggar akan ada sanksi atas pelanggarannya.

\section{Kinerja}

Anwar Prabu Mangkunegara (2009:67), mengemukakan bahwa: "Kinerja adalah hasil kerja secara kualitas dan kuantitas yang dicapai oleh seorang pegawai dalam melaksanakan tugasnya sesuai dengan tanggung jawab yang diberikan kepadanya".

\section{Kinerja Karyawan}

Menurut Mangkunegara (2019:75) pengertian kinerja adalah hasil kerja secara kualitas dan kuantitas yang dicapai oleh seorang pegawai dalam melaksanakan tugasnya sesuai dengan tanggung jawab yang diberikan kepadanya. Adapun indikator yang digunakan sebagai berikut:

\section{Model Penelitian}

Menurut pendapat Sugiyono (2018) "Model penelitian merupakan sintesa yang mencerminkan keterkaitan antara variabel yang diteliti dan merupakan tuntunan untuk memecahkan masalah penelitian serta merumuskan hipotesis yang berbentuk bagan alur yang dilengkapi penjelasan kualitatif". Dalam penelitian ini model penelitian yang dibuat sebagai berikut:

\section{Hipotesis Penelitian}

Menurut Sugiyono

"Hipotesis merupakan jawaban sementara terhadap masalah-masalah, karena sifatnya sementara maka perlu dibuktikan kebenarannya melalui data empirik yang terkumpul". Adapun rumusan hipotesis yang diajukan sebagai berikut:

$\mathrm{H} 1$ :Terdapat pengaruh yang signifikan disiplin kerja pada PT. Trans retail Indonesia..

$\mathrm{H} 2$ :Terdapat pengaruh yang signifikan kinerja PT. Trans retail Indonesia

$\mathrm{H} 3$ :Terdapat pengaruh yang signifikan disiplin kerja terhadap kinerja karyawan pada PT. Cipta Mega Sarana di Jakarta.

\section{METODE}

\section{Populasi}

Populasi dalam penelitian ini adalah semua karyawan PT. Transretail Indonesia pada tahun 2018 sejumlah 75 
orang karyawan.

\section{Sampel}

Teknik pengambilan sampling dalam penelitian ini adalah samplel jenuh, dimana semua anggota populasi dijasikan sebagai sampel. Dengan demikian sampel dalam penelitian ini berjumlah 75 responden.

\section{Jenis Penelitian}

Jenis penelitian yang dipakai adalah kuantitatif

\section{Teknik Analisis Data}

Dalam menganalisis data digunakan uji instrumen, uji asumsi klasik, regresi, koefisien determinasi dan uji hipotesis.

\section{a. Uji Instrumen}

Pada pengujian ini digunakan uji validitas dan uji reliabilitas.

1) Uji Validitas.

Uji validitas dimaksudkan untuk mengetahui ketepatan data tentang kesesuaian antara yang mau diukur dengan hasil pengukurannya. Untuk melakukan uji validitas dilihat nilai signifikansi 2 tailed dibandingkan dengan 0,05 dengan dengan ketentuan:

(a) Jika nilai signifikansi 2 talied < 0,05 , maka instrumen valid,

(b)Jika nilai signifikansi 2 talied > 0,05, maka instrumen tidak valid,

2) Uji Reliabilitas

Uji reliabilitas merupakan serangkaian pengukuran atau serangkaian alat ukur yang memiliki konsistensi bila pengukuran yang dilakukan dengan alat ukur itu dilakukan secara berulang. Instrumen yang baik tidak akan bersifat tendensius mengarahkan responden untuk memilih jawaban tertentu. Adapun kriteria yang digunakan sebagai berikut:

(a) Jika Cronbach's Alpha >0,600, maka instrumen reliabel.

(b) Jika Cronbach's Alpha $<0,600$, maka instrumen tidak reliabel.

\section{b. Uji Statistik}

1) Regresi Linier

Analisis regresi liner merupakan suatu teknik statistika yang digunakan untuk mencari persamaan regresi yang bermanfaat untuk meramal nilai variabel dependen berdasarkan nilai-nilai variabel independen. Dalam penelitian ini digunakan regresi linier berganda.

2) Koefisien Korelasi

Pengujian koefisien korelasi dimaksudkan untuk mengetahui tingkat kekuatan hubungan antara variabel independen dengan variabel dependen baik secara parsial maupun simultan".

3) Koefisien Determinasi

Analisis

koefisien

determinasi dimaksudkan untuk mengetahui besarnya pengaruh antara variabel independen terhadap variabel dependen baik secara parsial maupun simultan.

4) Uji Hipotesis

Pengujian

hipotesis

dimaksudkan untuk menentukan apakah suatu hipotesis sebaiknya diterima atau ditolak. Dalam penelitian ini digunakan uji $t$ (Parsial) dan uji F (Simultan).

\section{HASIL DAN PEMBAHASAN}

\section{Hasil Uji Instrumen}

a. Dari hasil pengujian diperoleh seluruh item kuesioner variabel pelatihan diperoleh nilai signifikansi 2 tailed sebesar $0,000<0,05$, dengan demikian instrumen valid.

b. Dari hasil pengujian diperoleh seluruh item kuesioner variabel kompensasi diperoleh nilai signifikansi 2 tailed sebesar $0,000<$ 0,05 , dengan demikian instrumen valid.

c. Dari hasil pengujian diperoleh seluruh item kuesioner variabel prestasi kerja diperoleh nilai signifikansi 2 tailed sebesar $0,000<$ 0,05 , dengan demikian instrumen valid. 
d. Dari hasil pengujian reliabilitas,

diperoleh hasil sebagai berikut:

Tabel 1. Uji Reliabilitas Variabel X (Disiplin Kerja)

\begin{tabular}{|c|c|c|c|c|c|c|c|c|c|c|c|}
\hline Butir & 1 & 2 & 3 & 4 & 5 & 6 & 7 & 8 & 9 & 10 & $\sum \mathrm{si}$ \\
\hline$\Sigma x i$ & 318 & 291 & 307 & 303 & 273 & 287 & 294 & 277 & 278 & 299 & \\
\hline$\Sigma x i 2$ & 1394 & 1169 & 1293 & 1261 & 1043 & 1135 & 1214 & 1083 & 1082 & 1237 & \\
\hline Si & 0,609 & 0,532 & 0,485 & 0,492 & 0,657 & 0,490 & 0,820 & 0,799 & 0,687 & 0,600 & 6,171 \\
\hline
\end{tabular}

Berdasarkan hasil pengujuan di atas, keseluruhan variabel disiplin (X1), Kinerja Karyawan (Y) diperoleh nilai cronbach alpha lebih besar dari 0,663 . Dengan demikian dinyatakan reliabel.

\section{Analisis Kuantitatif}

Pada analisis ini dimaksudkan untuk mengetahui pengaruh variabel independen terhadap variabel dependen. Adapun hasil pengujian sebagai berikut:

a. Analisis Regresi Linier Sederhana

Uji regresi ini dimaksudkan untuk mengetahui perubahan variabel dependen jika variabel independen mengalami perubahan. persamaan regresi linier sederhana yaitu: $\mathrm{Y}=19,093+0,518 X$

1) Konstanta sebesar 19,093 diartikan jika disiplin tidak ada, maka telah terdapat nilai prestasi kerja sebesar 19,093 point.

2) Koefisien regresi disiplin sebesar 0,518, angka ini positif artinya setiap ada peningkatan pelatihan sebesar 0,518 point maka prestasi kerja juga akan mengalami peningkatan sebesar 0,518 point.

3) Koefisien regresi kinerja sebesar 0,518 angka ini positif artinya setiap ada peningkatan kinerja sebesar 0,518 point maka prestasi kerja juga akan mengalami peningkatan sebesar 0,518 point.

\section{b. Analisis Koefisien Determinasi}

Analisis koefisien determinasi dimaksudkan untuk mengetahui besarnya persentase pengaruh dari variabel independen terhadap variabel dependen baik secara parsial maupun simultan. Adapun hasil pengujian sebagai berikut:

$$
\begin{aligned}
\mathrm{KD} & =r^{2} \quad \times 100 \% \\
& =0,515^{2} \times 100 \% \\
& =0,266 \times 100 \% \\
& =26,6 \%
\end{aligned}
$$

Artinya pengaruh Disiplin Kerja $(X)$ terhadap Kinerja Karyawan $(Y)$ adalah sebesar 26,6\%, sedangkan sisanya $73,4 \%$ dipengaruhi oleh faktor-faktor yang lain.

\section{c. Uji Hipotesis}

Pengujian hipotesis dengan uji $t$ digunakan untuk mengetahui hipotesis parsial mana yang diterima. Adapun hasil hasil perhitungan uji hipotesis di atas maka dapat dilihat bahwa, $t_{\text {hitung }}>t_{\text {tabel }}$ atau $6,14>1,666$ maka menunjukan hasil yang signifikan. Atau dengan kata lain $t_{\text {hitung }}>t_{\text {tabel }}$, maka $\mathrm{H}_{\mathrm{a}}$ diterima Ho ditolak, yang berarti bahwa terdapat pengaruh yang signifikan antara Disiplin Kerja terhadap kinerja karyawan PT Trans Retail Indonesia.

\section{Pembahasan Hasil Penelitian}

$\mathrm{H}_{\mathrm{a}}$ diterima Ho ditolak, yang berarti bahwa terdapat pengaruh yang signifikan antara Disiplin Kerja terhadap kinerja karyawan PT Trans Retail Indonesia.

\section{PENUTUP}

\section{Kesimpulan}

Disiplin kerja berpengaruh signifikan terhadap kinerja karyawan dengan kontribusi pengaruh sebesar $26,6 \%$. Uji hipotesis diperoleh nilai $t$ hitung $>\mathrm{t}$ tabel atau $(6,14>1,666)$.

2. Saran

a. Penulis menyarankan karyawan harus melakukan pekerjaan dengan 
sungguh-sungguh sesuai dengan standar yang telah ditetapkan oleh perusahaan, harus memiliki rasa tanggung jawab yang tinggi terhadap tugas yang telah diberikan.

b. Saran bagi peneliti selanjutnya adalah agar dilakukan penelitian lanjutan yang lebih khusus atau dengan variabel baru, misalnya kompensasi, jaminan, kepuasan kerja

\section{DAFTAR PUSTAKA}

Azwar, S. 2010. "Sikap Manusia Teori dan Pengukurannya", Pustaka Pelajar, Yogyakarta.

Azwar, Saifuddin. 2008. "Reliabilitas dan Validitas", Pustaka Pelajar, Yogyakarta.

Fahmi, Irham. 2011. "Analisis Laporan Keuangan", Alfabeta, Bandung.

Gaol, CHR. Jimmy L. 2014. "A to Z Human Capital (Manajemen Sumber Daya Manusia) Konsep, Teori, dan Pengembangan dalam Konteks Organisasi Publik dan Bisnis", PT. Gramedia Widiasarana, Jakarta.

Ghozali, Imam. 2012. "Aplikasi Analisis Multivariate dengan Program IBM
SPSS", Universitas Diponegoro, Yogyakarta.

Handoko, T. Hani. 2012. "Manajemen Personalia dan Sumber Daya Manusia", BPFE, Yogyakarta.

Hasibuan, S.P.M. 2011. "Manajemen Dasar, Pengertian, dan Masalah", CV. Haji Masagung, Jakarta.

Kustini, E., et al. (2021). Pengaruh Keterampilan Kerja Dan Lingkungan Kerja Terhadap Kinerja Karyawan Pada PT. Garuda Daya Pratama Sejahtera (Garuda Indonesia Group). Jurnal Ilmiah PERKUSI, 1(3), 305-314.

Mangkunegara, Anwar Prabu. 2009. "Evaluasi Kinerja Sumber Daya Manusia", Penerbit Refika Aditama, Bandung.

Mangkunegara, Anwar Prabu. 2011. "Manajemen Sumber Daya Manusia Perusahaan", Rosda, Bandung.

Sudaryono. 2012. "Metode Penelitian Pendidikan", Penerbit Prenada Media, Jakarta.

Suwanto, S., et al. (2021). Pengaruh Motivasi Dan Pengalaman Kerja Terhadap Produktivitas Karyawan Pada Happy Restaurant Di Bandung. Jurnal Ekonomi Efektif, 3(4), 546-554. 